\title{
Creative Accounting Scam at Satyam Computer Limited: How the Fraud Story Unfolded?
}

\author{
Madan Lal Bhasin \\ School of Accountancy, College of Business, Universiti Utara Malaysia, Sintok, Malaysia \\ Email: madan.bhasin@rediffmail.com
}

How to cite this paper: Bhasin, M.L. (2016) Creative Accounting Scam at Satyam Computer Limited: How the Fraud Story Unfolded? Open Journal of Accounting, 5, 5781.

http://dx.doi.org/10.4236/ojacct.2016.54007

Received: August 19, 2016

Accepted: September 23, 2016

Published: September 26, 2016

Copyright $\odot 2016$ by author and Scientific Research Publishing Inc. This work is licensed under the Creative Commons Attribution International License (CC BY 4.0).

http://creativecommons.org/licenses/by/4.0/

\begin{abstract}
Keen to project a perpetually rosy picture of the Satyam to the investors, employees and analysts, Mr. Raju (CEO and Chairman) manipulated the account books so that it appeared to be a far bigger enterprise than it actually was. The Satyam fraud has shattered the dreams of different categories of investors, shocked the government and regulators alike, and led to questioning of the accounting practices of statutory auditors and CG norms in India. An attempt has been made to provide an explanation for various "intriguing" questions about Satyam scam, such as: What was the need to commit a fraud on such a large scale? How Raju managed to cook-up books? What was Raju's real modus-operandi to manipulate the accounts for eight years? Why was Raju forced to blow his own whistle? Why was not there a stricter punitive action against the auditors of Satyam PwC?, etc." Now, after thorough investigations done by the CBI and SEBI, they have unveiled the methodology by which Satyam fraud was engineered. Finally, we recommend that "CA practices should be considered as a serious crime, and as such, accounting bodies, law courts and other regulatory authorities in India need to adopt very strict punitive measures to stop such unethical CA practices".
\end{abstract}

\section{Keywords}

Creative Accounting, Satyam Computer Services Limited, Modus Operandi Unveiled, Financial Statements, Corporate Governance, Auditors, Forensic Accounting, SEBI, SFIO, CID, India

\section{Introduction}

Creative Accounting (henceforth, CA) involves the "manipulation" of company financial records towards a "pre-determined" target. Unfortunately, few "loopholes" exist in the accounting standards, which provide "enough-rooms" for the use of CA practices. 
The present study of Satyam provides a "snapshot" of how Mr. Raju "master-minded" this maze of CA practices. Undoubtedly, the Satyam scam is clearly a glaring real-life corporate example of abuse of $\mathrm{CA}$, in which the account books were cleverly manipulated by following the modus-operandi of creating fake invoices, inflating revenues, falsifying the cash and bank balances, showing non-existent interest earned on fixed deposits, showing ghost employees, and so on. This type of CA is both illegal and unethical. In its recent indictment of the former promoters and top managers of Satyam, various investigative agencies (viz., SEBI, CBI, CID, SFIO, etc.) in India had finally provided minute and fascinating details about how India's largest corporate scam at Satyam was committed. An attempt has been made by the author, based on the media reports, to provide a description about the CA methodology used by the Satyam to commit the accounting fraud duly supported by evidence, wherever possible.

\section{Case Study of Creative Accounting Scam at Satyam}

The Satyam Computer Services Limited (hereinafter, "Satyam"), a global IT company based in India, has just been added to a notorious list of companies involved in fraudulent financial activities. Satyam's CEO, Mr. B. Ramalingam Raju (hereinafter, "Raju”), took responsibility for all the accounting improprieties that overstated the company's revenues and profits, and reported a cash holding of approximately $\$ 1.04$ billion that simply did not exist. "This leads one to ask a simple question: How does this keep on happening for five years, without any suspicions?” asked Bhasin [1]. So, while Raju ran his fraud, the auditor slept, the analysts slept, and so did the media. To be fair, the media and a whistle-blower did an excellent job of exposing Raju and his many other "shenanigans" after he had confessed [2]. In his letter (of Jan. 7, 2009) addressed to board of directors of Satyam, Raju showed the markers of this fraud "pathology". Now, more than six years later, the final decision in the Satyam scam has been made and all accused charge-sheeted in the case have been awarded punishment by the Court.

Satyam was a "rising-star" in the Indian 'outsourced' IT-services industry [3]. The company was formed in 1987 in Hyderabad (India) by Mr. Ramalinga Raju. The firm began with 20 employees, grew rapidly as a 'global' business, which operated in 65 countries around the world. Satyam was the first Indian company to be registered with three International Exchanges (NYSE, DOW Jones and EURONEXT). Satyam was as an example of India's growing success; it won numerous awards for innovation, governance, and corporate accountability [4]. As Bhasin [5] commented, "From 2003-2008, in nearly all financial metrics of interest to investors, the company grew measurably, as summarized in Table 1. Satyam generated Rs. 25,415.4 million in total sales in 2003 2004. By March 2008, the company sales revenue had grown by over three times. The company demonstrated an annual compound growth rate of $38 \%$ over that period. Similarly, operating profits, net profit and operating cash flows growth averaged 28, 33 and 35\%, respectively." Thus, Satyam generated significant corporate growth and shareholder value too. The company was a leading star (and a recognizable name) in a global IT marketplace. 
Table 1. Operating performance of Satyam: 2003 - 2004 to 2007 - 2008 (Rs. in million)

\begin{tabular}{ccccccc}
\hline Particulars & 2003-2004 & 2004- 2005 & 2005- 2006 & 2006-2007 & 2007-2008 & $\begin{array}{c}\text { Avera Growth } \\
\text { Rate (\%) }\end{array}$ \\
\hline Net Sales & $25,415.4$ & $34,642.2$ & $46,343.1$ & $62,284.7$ & $81,372.8$ & 38 \\
Operating Profit & 7743 & 9717 & $15,714.2$ & $17,107.3$ & $20,857.4$ & 28 \\
Net Profit & 5557.9 & 7502.6 & $12,397.5$ & $14,232.3$ & $17,157.4$ & 33 \\
Operating Cash Flow & 4165.5 & 6386.6 & 7868.1 & $10,390.6$ & $13,708.7$ & 35 \\
ROCE (\%) & 27.95 & 29.85 & 31.34 & 31.18 & 29.57 & 30 \\
ROE (\%) & 23.57 & 25.88 & 26.85 & 28.14 & 26.12 & 26 \\
\hline
\end{tabular}

Source: www.geogit.com.

Unfortunately, less than five months after winning the Global Peacock Award, Satyam became the center-piece of a "massive" accounting fraud. Bhasin [6] further added, “Satyam's top management simply cooked the company's books by overstating its revenues, profit margins, and profits for every single quarter over a period of 5 years, from 2003 to 2008." Shockingly, on January 7, 2009, Mr. Raju disclosed in a letter (see Exhibit 1. "He had been manipulating the company's accounting numbers for years. He overstated assets on Satyam's balance sheet by $\$ 1.47$ billion, and nearly $\$ 1.04$ billion in bank loans and cash that the company claimed to own was non-existent. Satyam also under-reported liabilities on its balance sheet and overstated its income nearly every quarter over the course of several years in order to meet analyst expectations." For example, the results announced on October 17, 2009 overstated quarterly revenues by $75 \%$ and profits by $97 \%$. Mr. Raju and company's global head of internal audit used a number of different techniques to perpetrate the fraud [7]. As Ramachandran [8] pointed out, "Using his personal computer, Mr. Raju created numerous bank statements to advance the fraud. He falsified the bank accounts to inflate the balance sheet with balances that did not exist. He also inflated the income statement by claiming interest income from the fake bank accounts. Mr. Raju also revealed that He created 6,000 fake salary accounts over the past few years and appropriated the money after the company deposited it." Here, Bhasin [9] pointed out, “The Satyam's global head of internal audit created fake customer identities and generated fake invoices against their names to inflate revenue. The global head of internal audit also forged board resolutions and illegally obtained loans for the company." It also appeared that the cash that the company raised through American Depository Receipts in the United States never made it to the balance sheets [10].

Indeed, the Satyam fraud activity dates back from April 1999, when the company embarked on a road to double-digit annual growth. As of December 2008, Satyam had a total market capitalization of $\$ 3.2$ billion dollars [11]. The fraud took place to divert company funds into real-estate investment, keep high earnings per share, raise executive compensation, and make huge profits by selling stake at inflated price. "The gap in the balance sheet had arisen purely on account of inflated profits over a period that lasted several years starting in April 1999. This gap reached unmanageable proportions 
Exhibit 1. Satyam's founder, chairman and CEO, Mr. Raju's letter to his board of directors.

To The Board of Directors,

7 January, 2009

Satyam Computer Services Ltd.

From: B. Ramalinga Raju

Chairman, Satyam Computer Services Ltd.

Dear Board Members,

It is with deep regret, and tremendous burden that I am carrying on my conscience, that I would like to bring the following facts to your notice:

1. The Balance Sheet carries as of September 30, 2008:

a) Inflated (non-existent) cash and bank balances of Rs. 5040 crore (as against Rs. 5361 crore reflected in the books); b) An accrued interest of Rs. 376 crore which is non-existent; c) An understated liability of Rs. 1230 crore on account of funds arranged by me; and d) An over stated debtors position of Rs. 490 crore (as against Rs. 2651 reflected in the books).

2. For the September quarter (Q2), we reported a revenue of Rs. 2700 crore and an operating margin of Rs. 649 crore ( $24 \%$ of revenues) as against the actual revenues of Rs. 2112 crore and an actual operating margin of Rs. 61 crore (3\% of revenues). This has resulted in artificial cash and bank balances going up by Rs. 588 crore in Q2 alone. The gap in the Balance Sheet has arisen purely on account of inflated profits over a period of last several years (limited only to Satyam standalone, books of subsidiaries reflecting true performance). What started as a marginal gap between actual operating profit and the one reflected in the books of accounts continued to grow over the years. It has attained unmanageable proportions as the size of company operations grew significantly (annualized revenue run rate of Rs. 11,276 crore in the September quarter, 2008 and official reserves of Rs. 8392 crore). The differential in the real profits and the one reflected in the books was further accentuated by the fact that the company had to carry additional resources and assets to justify higher level of operations - thereby significantly increasing the costs. Every attempt made to eliminate the gap failed. As the promoters held a small percentage of equity, the concern was that poor performance would result in a take-over, thereby exposing the gap. It was like riding a tiger, not knowing how to get off without being eaten. The aborted Maytas acquisition deal was the last attempt to fill the fictitious assets with real ones. Maytas' investors were convinced that this is a good divestment opportunity and a strategic fit. Once Satyam's problem was solved, it was hoped that Maytas' payments can be delayed. But that was not to be. What followed in the last several days is common knowledge.

I would like the Board to know:

1. That neither myself, nor the Managing Director (including our spouses) sold any shares in the last eight years-excepting for a small proportion declared and sold for philanthropic purposes.

2. That in the last two years a net amount of Rs. 1230 crore was arranged to Satyam (not reflected in the books of Satyam) to keep the operations going by resorting to pledging all the promoter shares and raising funds from known sources by giving all kinds of assurances (Statement enclosed, only to the members of the board). Significant dividend payments, acquisitions, capital expenditure to provide for growth did not help matters. Every attempt was 
made to keep the wheel moving and to ensure prompt payment of salaries to the associates. The last straw was the selling of most of the pledged share by the lenders on account of margin triggers.

3. That neither me, nor the Managing Director took even one rupee/dollar from the company and have not benefitted in financial terms on account of the inflated results.

4. None of the board members, past or present, had any knowledge of the situation in which the company is placed. Even business leaders and senior executives in the company, such as, Ram Mynampati, Subu D, T. R. Anand, Keshab Panda, Virender Agarwal, A. S. Murthy, Hari T, SV Krishnan, Vijay Prasad, Manish Mehta, Murali V, Sriram Papani, Kiran Kavale, Joe Lagioia, Ravindra Penumetsa, Jayaraman and Prabhakar Gupta are unaware of the real situation as against the books of accounts. None of my or Managing Director's immediate or extended family members has any idea about these issues.

Having put these facts before you, I leave it to the wisdom of the board to take the matters forward. However, I am also taking the liberty to recommend the following steps:

1. A Task Force has been formed in the last few days to address the situation arising out of the failed Maytas acquisition attempt. This consists of some of the most accomplished leaders of Satyam: Subu D, T. R. Anand, Keshab Panda and Virender Agarwal, representing business functions, and A. S. Murthy, Hari T and Murali V representing support functions. I suggest that Ram Mynampati be made the Chairman of this Task Force to immediately address some of the operational matters on hand. Ram can also act as an interim CEO reporting to the board.

2. Merrill Lynch can be entrusted with the task of quickly exploring some Merger opportunities.

3. You may have a 'restatement of accounts' prepared by the auditors in light of the facts that I have placed before you. I have promoted and have been associated with Satyam for well over twenty years now. I have seen it grow from few people to 53,000 people, with 185 Fortune 500 companies as customers and operations in 66 countries. Satyam has established an excellent leadership and competency base at all levels. I sincerely apologize to all Satyamites and stakeholders, who have made Satyam a special organization, for the current situation. I am confident they will stand by the company in this hour of crisis. In light of the above, I fervently appeal to the board to hold together to take some important steps. Mr. T.R. Prasad is well placed to mobilize support from the government at this crucial time. With the hope that members of the Task Force and the financial advisor, Merrill Lynch (now Bank of America) will stand by the company at this crucial hour, I am marking copies of this statement to them as well.

Under the circumstances, I am tendering my resignation as the chairman of Satyam and shall continue in this position only till such time the current board is expanded. My continuance is just to ensure enhancement of the board over the next several days or as early as possible.

I am now prepared to subject myself to the laws of the land and face consequences thereof.

Signature

(B. Ramalinga Raju)

Source: Letter distributed by the Bombay Stock Exchange and Security Exchange Board of India. Available at www.sebi.gov.in. 
as company operations grew significantly. Every attempt to eliminate the gap failed, and the aborted Maytas acquisition deal was the last attempt to fill the fictitious assets with real ones" [12]. But the investors thought it was a brazen attempt to siphon cash out of Satyam, in which the Raju family held a small stake, into firms the family held tightly. Fortunately, the Satyam deal with Maytas was "salvageable". It could have been saved only if "the deal had been allowed to go through, as Satyam would have been able to use Maytas' assets to shore up its own books." Raju, who showed "artificial” cash on his books, had planned to use this "non-existent" cash to acquire the two Maytas companies. To conclude, Bhasin [13] said, "the greed for money, power, competition, success, prestige etc. compelled Raju to 'ride the tiger', which led to violation of all duties imposed on him as fiduciaries: the duty of care, the duty of negligence, the duty of loyalty, and the duty of disclosure towards the stakeholders."

\section{Satyam Fraud Methodology Unveiled}

The unfolding of Satyam sage has been a watershed event in the Indian corporate history. According to the founder's own public confession, Satyam had inflated its reported revenues by $25 \%$, its operating margins by over 10 times, and its cash and bank balance by over 1 billion dollars. The magnitude of this fraud makes it by far the biggest accounting scandal in India's history [14] Now, it is good to see that the Satyam case is different at least in one respect-we now have all the details about the modus operandi of the fraud. In its recent indictment of the former promoters and top managers of Satyam, the various investigating agencies in India, such as, Securities and Exchange Board of India (SEBI), Special Fraud Investigation Office (SFIO), Crime Investigation Department (CID) and Central Bureau of Investigation (CBI) and so on have provided minute and fascinating details about how India's largest corporate scam was committed. As Bhasin [15] described, "SEBI's account reveals how stupendously easy it is to pull off financial fraud on a grand scale, even in publicly listed companies. Perpetrators often manage to evade the long-arm of the law. When they are brought to book, the actual details of the crime get lost in legal technicalities. And untangling the mess usually takes such a long time that, by the time the wrongdoer is hauled up, most people have forgotten what the crime was all about."

Shockingly, how did Raju mastermind this maze of Creative Accounting (CA) practices at Satyam? Keen to project a perpetually rosy picture of the company to the investors, employees and analysts, Raju manipulated the account books so that it appeared a far bigger enterprise than it actually was. Here, Bhasin [16] remarked, "The Satyam scam is clearly a case of abuse of creative accounting, in which the accounts were 'cooked-up' by creating fake invoices for the services not rendered, recognizing revenue on these fake receipts, falsifying the bank balances and interest on fixed deposits to show these fake invoices are converted into cash receipts and are earning interest, and so on." This type of CA is both illegal and unethical. In its recent indictment of the former promoters and top managers of Satyam, the SEBI and other investigative agencies in India had finally provided minute and fascinating details about how India's 
largest corporate scam was committed. An attempt has been made by the author to provide a brief description about the methodology used by the Satyam to commit the accounting fraud. An attempt has been made by the author (s), based on the media reports, to provide a description about the CA methodology used by the Satyam to commit the accounting fraud duly supported by evidence, wherever possible.

\subsection{Web of Companies}

A web of 356 investment companies was used to allegedly divert funds from Satyam. Under Ramalinga Raju, Satyam floated 327 companies and published inflated financials. These front companies purchased 6,000 acres of land, taken loans of Rs. 1230 crore from these companies, which were not even accounted in books. The CID investigation also revealed that Satyam had executed projects in the name of 7 non-existent companies: Mobitel, Cellnet, E Care, Synony, Northsea, Autotech and Hargreaves. All these companies had several transactions in the form of inter-corporate investments, advances and loans within and among them. One such "sister" company, with a paid-up capital of Rs. 5 lakh, had made an investment of Rs. 90.25 crore, and received unsecured loans of Rs. 600 crore.

Bhasin [17] remarked, "About Rs. 1425 crore, out of Rs 1744 crore loans obtained from non-banking finance companies were transferred to the bank accounts of Satyam by 37 entities as loans between November 17, 2006, and October 30, 2008, to meet the expenses of the company. Of this amount Rs. 194 crore was returned by the company between October and November 2008 to 15 out of the 37 companies. That left an outstanding liability of Rs. 1231 crore-the sum Raju says He infused into the company." The key puzzle the CBI was trying to solve was also about the claims of Raju, as per Jan. 7, 2009 letter, infusing Rs. 1230 crore into the company.

\subsection{Cooked-Up Books of Accounts}

Raju maintained thorough details of the Satyam's cooked-up accounts and minutes of meetings since 2002. He stored records of accounts for the latest year (2008-09) in a computer server called "My Home Hub." Details of accounts from 2002 till January 7, 2009 (the day Mr. Raju came out with his dramatic 5-page confession) were stored in two separate Internet Protocol (IP) addresses. Keeping in view the media reports, Bha$\sin [9]$ is of firm opinion that "Satyam's top management simply cooked the company's books by overstating its revenues, profit margins, profits, ghost employees etc. for every single quarter over a period of 5 years, from 2003 to 2008. In his letter, Raju admitted to inflating the cash and bank balances of the company by Rs. 5040 crore. The company's total assets as on Sept. 30, 2008, stood at Rs. 8795 crore. Of this cash and bank balances stood at Rs. 5313 crore (which was nearly $60 \%$ of the total assets). This was overstated by Rs. 5040 crore. The company basically had cash and bank balances of less than Rs. 300 crore."

Raju also admitted to fudging the last financial result that the company had declared, for the period of three months ending Sept. 30, 2008. The company had reported reve- 
nues of Rs. 2700 crore, with an operating margin of $24 \%$ of revenues (or Rs. 649 crore). According to Bhasin [1], "In fact, these numbers were made-up. The actual revenues were Rs. 2112 crore, with an operating margin of Rs. 61 crore (or 3\% of the total revenues). So, Satyam had made a profit of Rs. 61 crore but was declaring a profit of Rs. 649 crore. The difference was Rs. 588 crore. The operating profit for the quarter was added to the cash and bank balances on the balance sheet. Hence, cash and bank balances went up by an 'artificial' Rs. 588 crore, just for the three month period ending Sept. 30, 2008. This was a formula that Raju had been using for a while." First, Satyam over-declared its operating profit. Once this fudged amount of operating profit was moved to the balance sheet, it ended-up over-declaring its cash and bank balances. And this led to a substantially bigger balance sheet than was actually the case. The company had total assets of Rs. 8795 crore, as on September 30, 2008. Once the Rs. 5040 crore of cash and bank balances that were simply not there were removed from this, the "real" total assets fell to a significantly lower Rs. 3755 crore.

So, how did Raju managed to boost revenues? Here, Bhasin [17] provides an explanation as: "In order to do this, Raju created fictitious clients (to boot sales revenue) with whom Satyam had entered into business deals. In order to record the fake sales, Raju introduced 7000 fake invoices into the computer system of the company. Since the clients were fictitious, they could not make any real cash payments. Therefore, the company kept on inflating the money due from its fictitious clients (or what Raju called debtors position in his letter).Further, once fake sales had been recorded fake profits were also made and reported in accounts. Ultimately, the fake profits brought in fake cash, which therefore, needed to be invested somewhere. This led Raju to creating fake bank statements (showing forged fixed deposit receipts), where all the fake (or non-existed) cash that the company was throwing up was being invested. Finally, Raju tried his best to use this "fake cash" to buy out two real-estate companies, called Maytas Properties and Maytras Infra (both promoted by the family members) for a total value of $\$ 1.6$ billion. The idea was to introduce in company accounts some "real" assets against all the "fake" cash that the company had managed to accumulate, so far. Unfortunately, that did not happen, and after this, Raju had no other way out but to come clean. So, Raju finally confessed about fudging the accounts in his Letter." While the Satyam accounting scam, which involved unethical and illegal CA tactics, was to the tune of Rs. 8,000 crore. Shockingly, the scam had caused an estimated notional loss of Rs. 14,000 crore to investors and unlawful gains of Rs. 1900 crore to Ramalinga Raju and others.

The balance sheet of Satyam(as on September 30, 2008) carried an inflated (non-existent) cash and bank balances of Rs. 5040 crore, non-existent interest of Rs. 376 crore, and understatedly ability of Rs. 1230 crore. In fact, the balance sheet carried an accrued interest of Rs. 376 crore, which was non-existent. Table 2 depicts some parts of the Satyam's fabricated 'Balance Sheet and Income Statement' and shows the 'difference' between 'actual' and 'reported' finances. Keeping in view the modus operandi successfully used by Satyam, Bhasin [18] remarked: "To show excess cash, several banks have to be 
'fooled' (or asked to look the other way). They probably were. To show huge fake revenues, everyone, from sales teams to MIS managers to accountants, had to be kept in the 'dark' (or conscripted into the conspiracy). Some probably were. To hide it all from investors and analysts, auditors had to be 'fooled' (or roped in as co-conspirators). Some surely were. It is frightening that such large-scale fraud, which is precisely the kind of thing our various 'watchdogs' are meant to prevent, can be perpetrated so casually by just a few people at the top!"

\subsection{Falsification of Bank's Fixed Deposits Accounts}

The promoters of Satyam regularly used to generate monthly bank statements to be fed into the bankbooks. Similarly, they also used to generate confirmations of bank balances, at the end of every quarter, against non-existent fixed deposit receipt (FDRs) and interest earned/due thereon. As Bhasin [19] commented, "From the records of Satyam, as well as, the books held with the auditors, it was noted that two sets of letters of confirmation of balances of FDRs were available with the auditors. These two sets included confirmations actually sent by banks directly to the auditors (the genuine ones) in the prescribed format, and confirmations through forged letters purportedly sent from various bank branches, but forged." Thus, as on 30 Sept. 2008, while the actual FDs balances with various banks was just under Rs. 10 crore, fake FD receipts shown to the auditors totaled over Rs. 3300 crore. At HDFC Bank, for example, Satyam claimed Rs. 704 crore in deposits without having a single rupee parked with the bank branch concerned. With Citi Bank, it reported Rs. 613.32 crore of FDs when it actually had just Rs. 1.32 crore. And so on. Providing an explanation, Bhasin [20], described the motto and rationale for the process as, "Fake FDs had to be generated since fake business had to be shown to the stock markets, which meant the creation of fake customers and fake invoices from these businesses. Fake businesses generated fake revenues which, in turn, created the illusion of fake profit margins, and, finally, fake cash in the bank. Satyam apparently was very poor on its business fundamentals-with margins being low in many quarters, including negative margins in some quarters."

Indeed, falsification with regards to fixed deposit have been done since 2001-02 till 2007-08 and also for the quarter ended June 2008 and Sept. 2008. Further, Bhasin [16] observed, "All the misleading actions of window dressing and camouflaging created a

Table 2. Fabricated parts of balance sheet and income statement of Satyam.

\begin{tabular}{cccc}
\hline Items & Actual (Rs.) & Reported (Rs.) & Difference (Rs.) \\
\hline Cash and Bank Balances & 321 & 5361 & 5040 \\
Accrued Interest on bank FDs & Nil & 376.5 & 376 \\
Understated Liability & 1230 & None & 1230 \\
Overstated Debtors & 2161 & 2651 & 490 \\
Total & Nil & Nil & 7136 \\
Revenues (Q2 FY 2009) & 2112 & 2700 & 588 \\
Operating Profits & 61 & 649 & 588 \\
\hline
\end{tabular}


larger than life picturesque image year-after-year in the minds of millions of gullible investors whose fate underwent a depressive spin."Satyam's balance sheet (as on Sept. 7, 2008) carried an accrued interest of Rs. 376 crore, which was non-existent. These figures of accrued interest were shown in balance sheets in order to suppress the detection of such non-existent fixed deposits on account of inflated profits. As shown above in Table 3, the company had created a false impression about its fixed deposits summing to be about Rs. 3318.37 crore, while they actually held FDRs of just about Rs. 9.96 crore. Many experts cast partial blame for the scandal on Satyam's auditor Price Waterhouse $(\mathrm{PwC})$ India, because the fraud went undetected for so many years.

\subsection{Fake Invoices and Billing System}

By using the IT skills in-house and tampering with the invoice management system (IMS) of the company, a software module that was internally developed states (Bhasin) [21]. The Central Bureau of Investigation (CBI) has revealed details of the fake invoicing system used by Satyam. Documents released by two media reports [22] [23] to the general public in India showed how the company's standard billing systems were subverted to generate "false" invoices to show "inflated" sales, before its former boss, Ramalinga Raju, admitted to his role in the India's largest-ever corporate scandal. The investigators had used cyber forensics to uncover how in-house computer systems were exploited to generate fake invoices. Regular Satyam bills were created by a computer application called "Operational Real Time Management (OPTIMA)", which created and maintained information on all company projects. The "Satyam Project Repository (SRP)" system then generated project IDs; there is also an "Ontime" application for entering the hours worked by Satyam employees; and a "Project Bill Management System (PBMS)" for billing. An "Invoice Management System (IMS)" generated the final invoices.

From the above, an intriguing question that arises here is: "how were the fake invoices created by subverting the IMS?" In the IMS system, there is a mandatory field earmarked "Invoice Field Status". Unless this is filled, processing of the order does not go ahead. So, what Raju \& Company did was to use two alphabets "H" (Home) or "S"

Table 3. Falsification of fixed deposits accounts (Rs. in Crores).

\begin{tabular}{cccc}
\hline Financial Year & $\begin{array}{c}\text { Amount as per Balance } \\
\text { Sheet/Trial Balance }\end{array}$ & $\begin{array}{c}\text { Amount as per Bank } \\
\text { Confirmation }\end{array}$ & Amount Falsified \\
\hline $2001-02$ & 1243.15 & 5.43 & 7000.00 \\
$2002-03$ & 1252.37 & 0.00 & 1252.37 \\
$2003-04$ & 1465.33 & 1.89 & 1446.46 \\
$2004-05$ & 1801.47 & 5.97 & 1795.50 \\
$2005-06$ & 1906.47 & 1.11 & 1795.50 \\
$2006-07$ & 3364.94 & 5.65 & 3308.41 \\
$2007-08$ & 3316.93 & 8.53 & 3308.41 \\
Sept. 2008 & 3318.37 & 9.96 & 3308.41 \\
\hline
\end{tabular}

Source: SFIO Report published in the Pioneer (New Delhi), May 4, 2009, p 10. 
(Super) in the Invoice Field Status to process the entry. The invoices, thus created were "hidden" from the view of those who ran the finance units. There were about 74,625 invoices generated in the IMS between April 2003 and December 2008. About 7561 invoices out of 74,625 had "S" marked in their invoice field status. Out of this, 6603 were also found on the company's Oracle Financials software system, to make it seem like these were actual sales. Entries into this system get reflected straight in the Profit and Loss Statement. The balance of 958 invoices remained in the invoice state, and therefore, within the IMS system - they were not keyed into the Oracle enterprise-ware. The total revenues shown against these 7561 fake invoices were Rs. 5117 crore. Of this, sales through the "reconciled" 6603 invoices were about Rs. 4746 crore. The CBI has also found that "sales were inflated every quarter and the average inflation in sales was about $18 \%$. After generating fake invoices in IMS, a senior manager of the finance department (named Srisailam), entered the 6,603 fake invoices into Oracle Financials with the objective of inflating sales by Rs. 4746 crore. By reconciling the receipts of these invoices, the cash balances in the company's account were shown at Rs. 3983 crore.

The CBI officers have concluded that "the scandal involved this system structure being bypassed by the abuse of an emergency 'Excel Porting System', which allows invoices to be generated directly in IMS ... by porting the data into the IMS." This system was subverted by the creation of a user ID called "Super User" with "the power to hide/unhide the invoices generated in IMS." By logging in, as Super User, the accused were hiding some of the invoices that were generated through Excel Porting. Once an invoice is hidden the same will not be visible to the other divisions within the company but will only be visible to the company's finance division sales team. As a result, concerned business circles would not be aware of the invoices, which were also not dispatched to the customers. Investigation revealed that all the invoices that were hidden using the Super User ID in the IMS server were found to be false and fabricated. The face values of these fake invoices were shown as receivables in the books of accounts of Satyam, thereby dishonestly inflating the total revenues of the company.

\subsection{Showing Fake and Underutilized Employees}

To quote Bhasin [24], "One of the biggest sources of defalcation at Satyam was the inflation of the number of employees. Founder chairman of Satyam, Raju claimed that the company had 53,000 employees on its payroll. But according to investigators, the real number was around 43,000. The fictitious/ghost number of employees could be fabricated because payment to the remaining 13,000 employees was faked year-after-year: an operation that evidently involved the creation of bogus companies with a large number of employees." The money, in the form of salaries paid to ghost employees, came to around $\$ 4$ million a month, which was diverted through front companies and through accounts belonging to one of Mr. Raju's brothers and his mother to buy thousands of acres of land. Making up ghost employees might sound complicated, but investigators said it was not that difficult: "Employees are just code numbers in your system; you can create any amount of them by creating bogus employee IDs with false address, time-sheets, opening salary accounts with banks, and collecting payments 
through an accomplice."

Interestingly, the charge-sheet filed by the investigators is of the view that Satyam employees remained underutilized. For instance, the utilization level shown in the latest investor update by the company is about $74.88 \%$ for offshore employees. However, the actual utilization was $62.02 \%$.This clearly shows that the bench strength was as high as $40 \%$ in the offshore category. Further, as a result of underutilization, the company was forced to pay salaries to associates without jobs on hand, which increased the burden on company's finances. Even in the onshore category, the bench strength was around $5 \%$ (of total staff).

\subsection{Why Did Raju (Chairman) Need the Money?}

Indeed, it started with Raju's love for land and that unquenchable thirst to own more and more of it. Satyam planned to acquire a 51\% stake in Maytas Infrastructure Limited for $\$ 300$ million. The cash so raised was used to purchase several thousands of acres of land, across Andhra Pradesh, to ride a booming realty market. It presented a growing problem as facts had to be doctored illegally to keep showing healthy profits for Satyam that was growing rapidly, both in size and scale. Unfortunately, every attempt made by Raju to eliminate the gap ultimately failed. Cashing out by selling Maytas Infrastructure and Maytas Properties to Satyam for an estimated price of Rs. 7800 crore was the last straw.

Satyam had tried to buy two infrastructure company run by his sons, including Maytas, in December 2008. However, on Dec. 16, Satyam's board cleared the investment, sparking a negative reaction by investors, which pummeled its stock on the New York Stock Exchange and Nasdaq. The board hurriedly reconvened the same day a meeting and called off the proposed investment. Unfortunately, the matter did not die there, as Raju may have hoped. In the next 48 hours, resignations streamed in from Satyam's non-executive director, Krishna Palepu, and three independent directors. As Bhasin [20] reported, "The effort failed and in Jan. 2009 Raju confessed to irregularity on his own, and was arrested two days later. This was followed by the law-suits filed in the U.S. contesting Maytas deal." Four independent directors quit the Satyam board and SEBI ordered promoters to disclose pledged shares to stock exchanges. The trigger was obviously the failed attempt to merge Maytas with Satyam.

\subsection{Lax Board of Directors}

The Satyam Boardwas composed of "chairman-friendly" directors, who failed to question the management's strategy and use of leverage in recasting the company. Moreover, they were also extremely slow to act when it was already clear that the company was in financial distress. Here, Bhasin [25] observed, "The directors acted as mere rubber stamps and the promoters were always present to influence the decision. The glue that held the board members together was Mr. Ramalinga Raju (Chairman). Each of the board members were there on his personal invitation and that made them ineffective. The Board ignored, or failed to act on, critical information related to financial wrong- 
doings before the company ultimately collapsed." It was only when Raju in the Dec. 2008 announced a $\$ 1.6$ billion bid for two Maytas companies (Maytas Infra and Maytas Properties) and while the share market reacted very strongly against the bid and prices plunged by $55 \%$ on concerns about Satyam's CG, that some of the independent directors came into action by announcing their withdrawal from the Board, by than it was too late.

Satyam board's investment decision to invest 1.6 billion dollars to acquire a $100 \%$ stake in Maytas Properties and in 51\% stake in Maytas Infrastructure (the two real estate firms promoted by Raju's sons) was in gross violation of the Companies Act 1956, under which no company is allowed, without shareholder's approval to acquire directly or indirectly any other corporate entity that is valued at over $60 \%$ of its paid-up capital. "Yet, Satyam's directors went along with the decision, raising only technical and procedural questions about SEBI's guidelines and the valuation of the Maytas companies. They did not even refer to the conflict of interest in buying companies in a completely unrelated business, floated by the chairman's relatives," remarked Bhasin [16]. Indeed, one of the independent directors, Krishna Palepu, praised the merits of real-estate investment on Satyam's part.

\subsection{Unconvincing Role of Independent Directors}

With regard to the role of the "independent" directors (IDs) at Satyam, we should understand: how "independent" they actually were? It was seen that all the non-executive directors (NEDs) at Satyam have been allotted significant stock options at an unbelievable low strike price of Rs. 2 per share, and apart from this, all the NEDs have also earned handsome commissions during 2007 - 2008, as reflected by Satyam's audited results. Table 4 shows the details of number of Stock options and commission given to different NEDs, as per Satyam's audited results for 2007 - 2008.

Naturally, a basic question that arises here is: "how can directors who had enjoyed such a huge largesse from the Company's promoters, had been beneficiaries of stock options given at an unbelievable strike price of Rs. 2 per share (against the ruling price of Rs. 500 per share in 2007 - 2008) and who had received such high commissions could be expected to be "independent"? According to Bamahros and Bhasin [26], "The idea of giving stock options to the independent directors, was perhaps, an intelligent ploy by Raju to successfully implement his plot at Satyam, with little resistance from the so-called independent directors, to whom, he was supposed to report to. It sounds ridiculous to listen to some of the independent directors at the Press interviews post-scandal that they were not aware of what was going on at Satyam."Furthermore, it is very disturbing that highly respected persons like T. R. Prasad and Dr. Rammohan Rao, both received stock options and commissions from Satyam, without wondering how this was acceptable to their status of independent directors. Take the case of another independent director, the well-known Prof. Krishna Palepu. Prof. Palepu accepted more than $\$ 200,000$ in total compensation along with 10,000 stocks (equivalentto $5000 \mathrm{ADR}$ ) and getting paid a fabulous fee of Rs. 9.2 million for conducting trai- 
Table 4. Satyam's sumptuous gift to its non-executive directors.

\begin{tabular}{ccc}
\hline Name & No. of Options & Commission (in Rs.) \\
\hline Krishna Palepu & 10,000 & 1.2 millon \\
Mangalam Srinivasan & 10,000 & 1.2 million \\
T R Prasad & 10,000 & 1.13 million \\
V P Rama Rao & 10,000 & 0.1 million \\
M Ram Mohan Rao & 10,000 & 1.2 million \\
V S Raju & 10,000 & 1.13 million \\
Vinod Dham & 10,000 & 1.2 million \\
\hline
\end{tabular}

Source: Satyam's Balance Sheet for 2007-08, Satyam Computer Services Limited, Hyderabad.

ning programs for Satyam employees on CG principles and their compliance, even if not expressly forbidden statutorily, will still place him as one having a vested interest in accepting the unethical policy of the management as a quid pro quo. As an "independent" director, he should not have accepted any consulting assignment from Satyam. "Satyam scam is one more proof that the mere compliance of SEBI's rule of the minimum number of independent directors does not guarantee ethical practices. Corporate history of the past decade has more than clearly shown that independent directors have not served their purpose," stated Bhasin [24] [27].

Notwithstanding Raju's confession, the Satyam episode has brought into sharp focus the role and efficacy of "independent" directors. The SEBI requires the Indian publicly held companies to ensure that independent directors make up at least half of their board strength. The knowledge available to independent directors and even audit committee members was inherently limited to prevent willful withholding of crucial information. The reality was, at the end of the day, even as an audit committee member or as an independent director, I would have to rely on what the management was presenting to me, drawing upon his experience as an independent director and audit committee member. As Bhasin [13] pointed out, "It is the auditors' job to see if the numbers presented are accurate. That is what the directors should have been asking... Like the dog that did not bark in the Sherlock Holmes story, the matter was allowed to slide. Even if outside directors were unaware of the true state of Satyam's finances, some 'red' flags should have been obvious." The closely-held structure of many Indian companies suggests a need for improved transparency and accountability for independent directors. Apart from improving disclosure standards, re-auditing norms, and greater shareholder activism, there is also a need to counter corruption.

\subsection{Tunneling Strategy Used by Satyam}

As part of their "tunneling" strategy, the Satyam promoters had substantially reduced their holdings in company from 25.6\% (in March 2001) to 8.74\% (in March 2008). Furthermore, as the promoters held a very small percentage of equity (mere $2.18 \%$ ) on December 2008, as shown in Table 5, the concern was that poor performance would result in a takeover bid, thereby exposing the gap. The aborted Maytas acquisition deal was the final, desperate effort to cover up the accounting fraud by bringing in some real 
assets into the business. When that failed, Raju confessed the fraud. Given the stake the Raju's held in Matyas, pursuing the deal would not have been terribly difficult from the perspective of the Raju family.

As pointed out by Shirur [28], "Unlike Enron, which sank due to agency problem, Satyam was brought to its knee due to tunneling. The company with a huge cash pile, with promoters still controlling it with a small per cent of shares (less than $3 \%$ ), and trying to absorb a real-estate company in which they have a majority stake is a deadly combination pointing prima facie to tunneling." The reason why Ramalinga Raju claims that he did it was because every year he was fudging revenue figures and since expenditure figures could not be fudged so easily, the gap between "actual" profit and "book" profit got widened every year. In order to close this gap, he had to buy Maytas Infrastructure and Maytas Properties. In this way, "fictitious" profits could be absorbed through a "self-dealing" process. Bhasin [6] concludes, "The auditors, bankers, and SEBI, the market watchdog, were all blamed for their role in the accounting fraud."

\subsection{Insider Trading Activities at Satyam}

Investigations into Satyam scam by the CID of the State Police and Central agencies have established that "the promoters indulged in nastiest kind of insider trading of the company's shares to raise money for building a large land bank." According to the SFIO Report [29] findings, "promoters of Satyam and their family members during April 2000 to January 7, 2009 sold almost 3.9 crore number of shares thereby collecting in Rs. 3029.67 crore. During this course, the founder ex-chairman Ramalinga Raju sold 98 lakh shares collecting in Rs. 773.42 crores, whereas, his brother Rama Raju, sold 1.1 crore shares pocketing Rs. 894.32 crores." Finding these top managers guilty of unfair manipulation of stock prices and insider trading, SEBI has asked them to deposit their 'unlawful gains' of Rs. 1850 crore, with 12\% interest, with the regulator within 45 days. They have also been barred from associating with the securities markets in any manner for the next 14 years.

\subsection{Gaps in Satyam's Earnings and Cash Flows}

Through long and bitter past experience, some investors have developed a set of early warning signs of financial reporting fraud. Bhasin [30] described it as: "One of the strongest is the difference between income and cash flow. Because overstated revenues cannot be collected and understated expenses still must be paid, companies that misreport income often show a much stronger trend in earnings than they do in cash flow from operations." But now, we can see there is no real difference in the trends in Satyam's net income and its cash flow from operations during 2004 and 2005, as shown in

Table 5. Promoter's Shareholding pattern in Satyam

\begin{tabular}{cccccccccc}
\hline Particulars & $\begin{array}{c}\text { March } \\
\mathbf{2 0 0 1}\end{array}$ & $\begin{array}{c}\text { March } \\
\mathbf{2 0 0 2}\end{array}$ & $\begin{array}{c}\text { March } \\
\mathbf{2 0 0 3}\end{array}$ & $\begin{array}{c}\text { March } \\
\mathbf{2 0 0 4}\end{array}$ & $\begin{array}{c}\text { March } \\
\mathbf{2 0 0 5}\end{array}$ & $\begin{array}{c}\text { March } \\
\mathbf{2 0 0 6}\end{array}$ & $\begin{array}{c}\text { March } \\
\mathbf{2 0 0 7}\end{array}$ & $\begin{array}{c}\text { March } \\
\mathbf{2 0 0 8}\end{array}$ & $\begin{array}{c}\text { Dec. } \\
\mathbf{2 0 0 8}\end{array}$ \\
\hline $\begin{array}{c}\text { Promoter's holding } \\
\text { (in\% - age) }\end{array}$ & 25.6 & 22.26 & 20.74 & 17.35 & 15.67 & 14.02 & 8.79 & 8.74 & 2.18 \\
\hline
\end{tabular}


Figure 1 below. Both net income and cash flow lines were almost overlapping each other for 2004 and 2005. That is not because the earnings were genuine; it is because the cash flows were manipulated too. To do that, Raju had to forge several big amount accounts receivables, and simultaneously falsify about their cash collections. Thus, the fake cash flows had led to the bogus bank balances. If cash flow from operating activities of a company is consistently less than the reported net income, it is a warning sign. The investor must ask why operating earnings are not turning into cash. To keep from tripping the income-cash flow alarms, Raju had to manipulate almost every account related to operations. However, wide gaps can be noticed in net income and cash flow from operation during 2006, 2007 and 2008, respectively. "During 2006 to 2008, cash flows were far less than net income due to accounting manipulations. Indeed, Satyam fraud was a stunningly and very cleverly articulated comprehensive fraud, likely to be far more extensive than what happened at Enron," said Bhasin [31].The independent board members of Satyam, the institutional investor community, the SEBI, retail investors, and the external auditor-none of them, including professional investors with detailed information and models available to them, detected the malfeasance.

\subsection{Fake Audit and Dubious Role Played by Auditor's}

Many experts cast partial blame for the CA scandal on Satyam's auditor 'Price Waterhouse $(\mathrm{PwC})$ ' India, because the fraud went undetected for so many years. In fact, global auditing firm used Lovelock and Lewis as their agent, who audited the Satyam's books of accounts from June 2000 until the discovery of the fraud in 2009. Several commentators criticized PwC harshly for failing to detect the fraud [32]. As Bhasin [24] stated, "The PwC India signed Satyam's financial statements and hence it, was responsible for the numbers under the Indian law. The fraudulent role played by the $\mathrm{PwC}$ in the failure of Satyam matches the role played by Arthur Anderson in the collapse of Enron.” However, Mr. S. Goplakrishnan and Mr. S. Talluri, partners of PwC had admitted they did not come across any case or instance of fraud by the company. However, Raju's admission of having fudged the accounts for several years put the role ofthese statutory auditors on the dock.

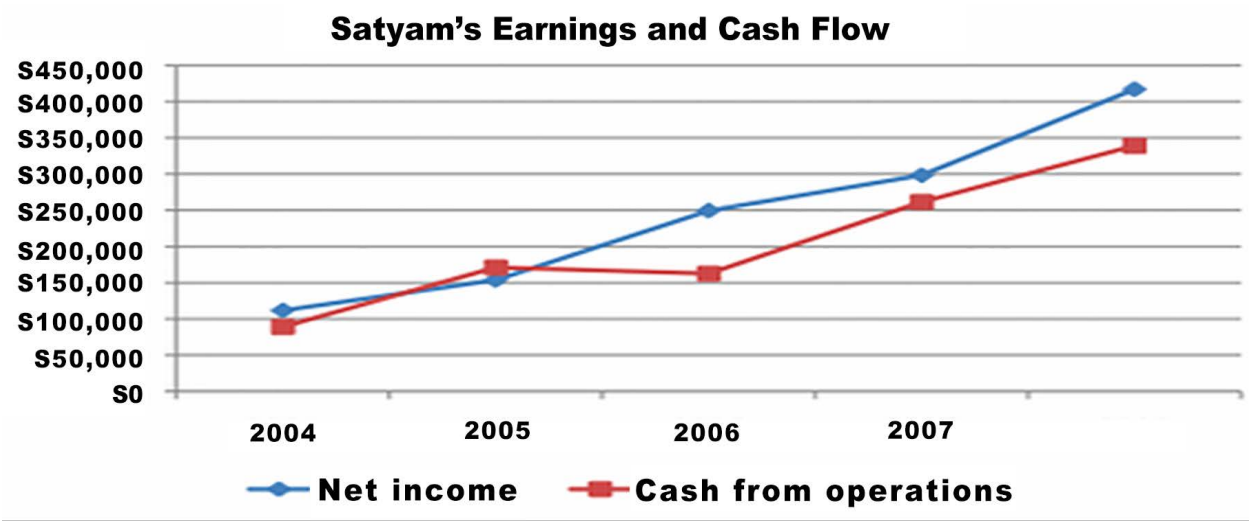

Figure 1. Satyam's earnings and cash flow. 
The SFIO Report [29] stated that "the statutory auditors instead of using an independent testing mechanism used Satyam's investigative tools and there by compromised on reporting standards." PwC did not check even 1\% of the invoices; neither did they pay enough attention to verification of sundry debtors, which (according to Raju's confession) was overstated by $23 \%$ (SFIO report says it was overstated by almost $50 \%$ ). The Statutory auditors also failed in discharging their duty when it came to independently verifying cash and bank balances, both current account and fixed deposits. Hence, it was required that the auditors $(\mathrm{PwC})$ independently checked with the banks on the existence of fixed deposits, but this was not done for as large as a sum of Rs. 5,040 crore. "The statutory auditors on whom the general public relied on for accurate information not only failed in their job but themselves played a part in perpetrating fraud by preparing a clean audit report for fudged, manipulated and cooked books," concluded Bhasin [24]. It is shocking to know that "PwC outsourced the audit function to some audit firm, Lovelock and Lewis, without the approval of Satyam.”

To be fair, there were probably thousands of Satyam cash accounts that had to be confirmed by the auditor, as the outsourcer has nearly 700 customers (including 185 Fortune 500 companies) in 65 countries. The audits for a company of that size would have been staggered, with millions of dollars of outstanding receivables pouring in to different locations at any given time. As Veena et al. [33] commented, "The Satyam case focuses on auditors' responsibilities related to obtaining and evaluating audit evidence, particularly as it relates to confirming cash and receivables. It also explores the quality control responsibilities related to audit procedures performed by foreign affiliates of a large international audit firm." One particularly troubling item concerned the $\$ 1.04$ billion that Satyam claimed to have on its balance sheet in "non-interest-bearing" deposits. Bhasin [9] pointed out, "The large amount of cash should have been a 'red-flag' for the auditors that further verification and testing were necessary. While verifying bank balances, they relied wholly on the (forged) fixed deposit receipts and bank statements provided by the 'Chairman's office'. As to the external auditors, who are supposed to look out for investors, they seem to have been quite a trusting lot. "The forensic audit reveals differences running into hundreds of crores of Rupees. Between the fake and real statements, as captured by the computerized accounting systems. But for some strange reason, everyone, from the internal auditor to the statutory auditors, chose to place their faith in the 'Chairman's office' rather than the company's information systems, stated Bhasin [15]. Furthermore, it appears that the auditors did not independently verify with the banks in which Satyam claimed to have deposits. Unfortunately, the PwC audited the company for nearly 9 years and did not uncover the fraud, whereas Merrill Lynch discovered the fraud as part of its due diligence in merely 10 days. Missing these "red-flags" implied either that the auditors were grossly inept or in collusion with the company in committing the fraud.

When scams break out in the private sector auditors too end up on the firing line. The CBI, which investigated the Satyam fraud case, also charged the two auditors with complicity in the commission of the fraud by consciously overlooking the accounting 
irregularities. On April 22, 2014 "The Institute of Chartered Accountants of India (ICAI)" [34] has imposed a life-time ban on four auditors (Mr. S. Gopalakrishna, Mr. Talluri Srinivas, Mr. V. Srinivasa and Mr. V.S. Prabhakara Rao) involved in the Satyam CA fraud. All of them had been found guilty of gross negligence in discharge of their duties by the Disciplinary Committee of ICAI and they were barred from practicing as a Chartered Accountant. A penalty of Rs. 5 lakh each was also levied on them. Strangely, Satyam's auditor, PwC, got away with a rap on its knuckles.

\subsection{Abnormal Audit Fees Paid to PwC India Agent}

A point has also been raised about the unjustified increase in audit fees. A reference to the figures of audit fee in comparison with total income over a period of time may be pertinent. Table 6 shows that over a period of four years, 2004 - 2005 to 2007 - 2008, the audit fee increased by 5.7 times, whereas total income increased by 2.47 times during the same period. Here, Bhasin [5] remarked, "Nevertheless, it is difficult to draw any conclusion as to whether the increase in audit fee was justified or not. Suspiciously, Satyam also paid $\mathrm{PwC}$ twice what other firms would charge for the audit, which raises questions about whether PwC was complicit in the fraud." Another development that came under investigators lens was that between 2003- 2008, audit fee from Satyam had increased three times. For instance, Satyam's auditor's fee jumped from Rs. 92 lakhs in 2004-05 fiscal to Rs. 1.69 crore the next year. But it was the financial year 2006-07 when PwC's auditing fees shot phenomenally to Rs. 4.31 crores. The Chairman of the AC's in the relevant years should have been interrogated by the investigators as to what justification did the AC have for recommending such a hike?

The Price Waterhouse received an annual fee of Rs. 37.3 million (or Rs. 4.31 crore) for financial year 2007-2008, which is almost twice, as what Satyam peers (i.e., TCS, Infosys, Wipro),on an average, pay their auditors. Bhasin [15] stated, "This shows that the auditors were being lured by the monetary incentive to certify the cooked and manipulated financial statements. Events of such nature raise doubts about statutory auditors' discharging their duty independently." Consequently, on $24^{\text {th }}$ Jan. 2009, two senior partners of PwC, Mr. S. Gopalakrishna (was due for retirement by March 09) and Mr. Srinivas Talluri were booked by Andhra Pradesh CID police on charges of fraud and criminal conspiracy. The PwC has suspended the two partners, who signed on Satyam's balance sheet and are currently in prison. The SFIO report also states that Pw Coutsourced the audit function to some audit firm, "Lovelock and Lewis," without the approval of Satyam.

Table 6. Satyam's total income and audit fees (Rs. in millions).

\begin{tabular}{ccccc}
\hline Year & 2004 - 05 & 2005-06 & 2006-07 & 2007 - 08 \\
\hline Total Income (A) & 35,468 & $50,122.2$ & $64,100.8$ & $83,944.8$ \\
Audit Fees (B) & 6.537 & 11.5 & 36.7 & 37.3 \\
\% of B to A & 0.0184 & 0.0229 & 0.0573 & 0.0444 \\
\hline
\end{tabular}

Source: Annual Reports of Satyam, Percentage computed. 


\subsection{Questionable Role of the Audit Committee}

As Bhasin [9] strongly observed, "Surprisingly, the failure to detect the Satyam fraud is 'unimaginable' because it involves violating basic audit procedures. Auditing cash is so basic that people do not think twice about accepting the number, never thinking to ask questions about it." Still, a basic question arises: "Where was the Audit Committee (AC)?" As an AC member, we understand that board members are not responsible for re-auditing financial statements. However, the directors have access to the auditors and the right and responsibility to question the audit. For instance, in the case of seeing an accumulated $\$ 1$ billion on the books, the AC should have raised questions about what the company planned to do with the cash, or how much it was earning on the money, and so on. It also has been suggested that the Public Committee on Accounting Oversight Board (PCAOB) - the U.S. entity charged with auditing firm oversight-bears some responsibility for the alleged poor performance of Price Waterhouse India. Unfortunately, one possible culprit that escaped blame for the Satyam scandal is the accounting rules used by the company. Satyam used both U.S. GAAP and IFRS to report its financial results, which means that one set of accounting standards did not trump the other with respect to shedding light on the fraud. The realization that accounting rules neither helped nor hindered the fraud should help to quell some of the fierce debate regarding which accounting standards are more transparent and therefore better for investors: U.S. GAAP or IFRS.

Moreover, Bhasin [20] observed that "the timely action on the information supplied bya whistleblower to the chairman and members of the AC (an e-mail dated December18, 2008 by Jose Abraham), could serve as an SOS to the company, but, they chose to keep silent and did not report the matter to the shareholders or the regulatory authorities." The Board members on AC, who failed to perform their duties alertly be therefore tried out under the provisions of the Securities Contracts (Regulation) Act, 1956 (an unimaginable fine extendable to Rs. 25 crore but also including imprisonment for a term, which may extent to 10 years).

\section{The Aftermath of Satyam Scandal}

At its "peak" market-capitalization, Satyam was valued at Rs. 36,600 crore in 2008. Following the shocking disclosure, the traders counter saw frantic selling on the bourses and nearly 143 million shares (or a quarter of the total 575 million shares) had changed hands and finally, the shares closed down $77.69 \%$ at Rs. 39.95 at the Bombay Stock Exchange (BSE), wiping out Rs. 139.15 per share in a single day. After Wednesday's fall, the firm's market value has sunk to little more than $\$ 500$ million from around $\$ 7$ billion as recently as last June. The stock that hit its all-time high of Rs. 542 in 2008 crashed to an unimaginable Rs. 6.30 on the day Raju confessed on January 9, 2009. Satyam's shares fell to 11.50 rupees on January 10, 2009, their lowest level since March 1998, compared to a high of Rs. 544 in 2008. In the New York Stock Exchange, Satyam shares peaked in 2008 at US $\$ 29.10$; by March 2009 they were trading around US $\$ 1.80$. Thus, investors lost $\$ 2.82$ billion in Satyam. 
Criminal charges were brought against Mr. Raju, including: criminal conspiracy, breach of trust, and forgery. After the Satyam fiasco and the role played by $\mathrm{PwC}$, investors became wary of those companies who are clients of $\mathrm{PwC}$, which resulted in fall in share prices of around 100 companies varying between $5 \%-15 \%$. The news of the scandal (quickly compared with the collapse of Enron) sent jitters through the Indian stock market, and the benchmark Sensex index fell more than 5\%. Shares in Satyam fell more than 70\%. The graph, "Fall from Grace," shown in Figure 2, depicts the Satyam's stock decline between December 2008 and January 2009.

Just a year later, the scam-hit Satyam was snapped up by Tech Mahindra for a mere Rs. 58 per share-a market cap of mere Rs. 5600 crore. In the aftermath of Satyam, India's markets recovered and Satyam now lives on. India's stock market is currently trading near record highs, as it appears that a global economic recovery is taking place. Civil litigation and criminal charges continue against Satyam. Shubhashish [35] concluded, "On 13 April 2009, via a formal public auction process, a 46\% stake in Satyam was purchased by Mahindra \& Mahindra owned company Tech Mahindra, as part of its diversification strategy. Effective July 2009, Satyam rebranded its services under the new Mahindra management as Mahindra Satyam. After a delay due to tax issues, Tech Mahindra announced its merger with Mahindra Satyam on 21 March 2012, after the board of two companies gave the approval. The companies are merged legally on 25 June 2013." As Winkler [32] states, "With the right changes, India can minimize the rate and size of accounting fraud in the Indian capital markets."

\section{Investigation into the Satyam Case: Criminal\& Civil Charges}

The Indian government immediately started an investigation, while at the same time limiting its direct participation. According to Bhasin [36], "The government appointed a 'new' board of directors for Satyam to try to save the company: goal was to sell the company within 100 days. On 7 Jan. 2009, the Securities and Exchange Board of India (SEBI) commenced investigations under the various SEBI regulations. The Ministry of Corporate Affairs (MCA) of the Central Government separately initiated a fraud investigation through its Serious Fraud Investigation Office (SFIO). In addition, the MCA filed a petition before the Company Law Board (CLB) to prevent the existing directors from acting on the Board and to appoint new directors. On 9 Jan. 2009, the CLB sus-

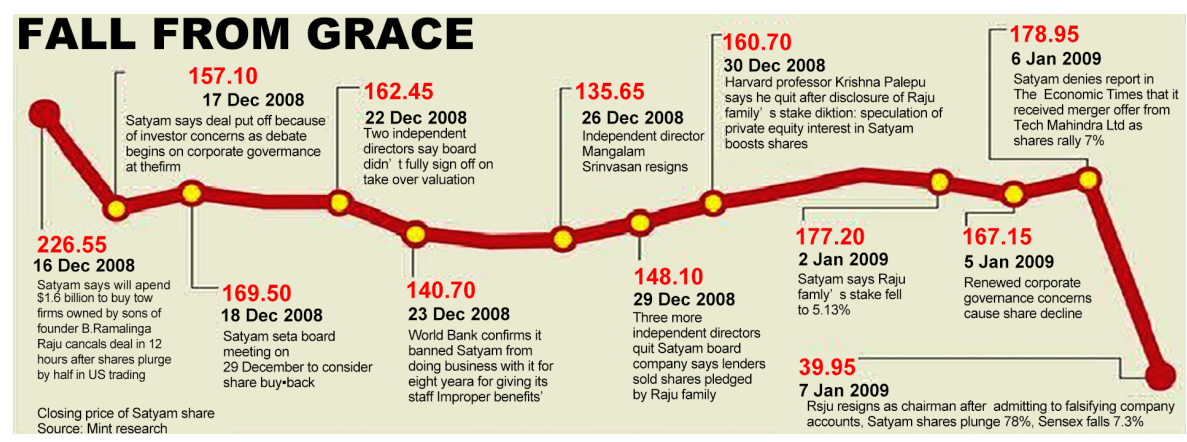

Figure 2. Stock charting of Satyam from December 2008 to January 2009. 
pended the current directors of Satyam and allowed the Government to appoint up to 10 new 'nominee' directors. Subsequently, the new, six-member Board had appointed a chief executive officer and external advisors, including the accounting firms KPMG and Deloitte to restate the accounts of Satyam."

"The Satyam fraud has highlighted the multiplicity of regulators, courts and regulations involved in a serious offence by a listed company in India. The lengthy and complicated investigations that were followed up after the revelation of the fraud has led to charges against several different groups of people involved with Satyam," says Bhasin [5]. Indian authorities arrested Mr. Raju, Mr. B. Ramu Raju (Raju's brother), its former managing director, Mr. Srinivas Vdlamani, the company's head of internal audit, and its CFO on criminal charges of fraud. Indian authorities also arrested and charged several of the company's auditors $(\mathrm{PwC})$ with fraud. The Institute of Chartered Accountants of India (ICAI) [37] ruled that "the CFO and the auditor were guilty of professional misconduct." The CBI is also in the course of investigating the CEO's overseas assets. There were also several civil charges filed in the U.S. against Satyam by the holders of its ADRs. The investigation also implicated several Indian politicians. Both civil and criminal litigation cases continue in India and civil litigation continues in the United States.

All the accused involved in the Satyam fraud case, including Raju, were charged with cheating, criminal conspiracy, forgery, breach of trust, inflating invoices, profits, faking accounts and violating number of income tax laws. The CBI had filed three chargesheets in the case, which were later clubbed into one massive charge-sheet running over 55,000 pages. Over 3000 documents and 250 witnesses were parsed over the past 6 years. A special CBI court on April 9, 2015 finally, sentenced Mr. B. Ramalinga Raju, his two brothers and seven others to seven years in prison in the Satyam fraud case. The court also imposed a fine of Rs. 5 crore on Ramalinga Raju, the Satyam Computer Services Ltd's founder and former chairman, and his brother B Rama Raju, and Rs. 20-25 lakh each on the remaining accused. The 10 people found guilty in the case are: B. Ramalinga Raju; his brother and Satyam's former managing director B. Rama Raju; former chief financial officer Vadlamani Srinivas; former PwC auditors Subramani Gopalakrishnan and T. Srinivas; Raju's another brother, B Suryanarayana Raju; former employees (G. Ramakrishna, D. Venkatpathi Raju and Ch. Srisailam); and Satyam's former internal chief auditor V.S. Prabhakar Gupta.

\section{Conclusions}

The Satyam scam was clearly a glaring example of "abuse" of CA, in which the account books were cooked up. The purpose was to inflate the share price of the company and sell the promoters holding at inflated price. As a result of this fraud, the share of the company fell drastically thus, wiping out Rs. 9376 crores of investors' wealth in just one single day. Moreover, Satyam investigators have uncovered "systemic" insider trading. The ED claims to have found prima facie evidence against Raju and others of violating the Prevention of Money Laundering Act. Sources at the SFIO revealed to the Press that 
several institutional investors dumped shares in the firm on "large scale" up to two days before Ramalinga Raju confessed to "wildly" inflate the company's assets and profitability. Most of the sales seemed to have taken place after Satyam failed in the bid to acquire Maytas Infra and Maytas Properties. Even to a casual observer of the Satyam fiasco, the enormity of the scandal was a great eye-opener.

The CA scam committed by the founders of Satyam is a testament to the fact that the science of conduct is swayed in large by human greed, ambition, and hunger for power, money, fame and glory. Bhasin [17] lucidly pointed out that "the culture at Satyam (especially dominated by the board) symbolized an unethical culture". The debacle of Satyam raised a debate about the role of CEO in driving an organization to the heights of success and its relation with the board members and various core committees. This scam brought to light the role of CG in shaping the protocols related to the working of Audit Committee and duties of Board members. At last, Tech Mahindra purchased $51 \%$ of Satyam shares on April 16, 2009, and successfully saved the firm from a complete collapse. Undoubtedly, the inability of stock analysts to identify the "gaps" in Satyam's books and ring warning bells proved costly for investors.

Now, it is amply clear that the Satyam scam was plotted at the top and driven by Ramalinga Raju and his brother. They were the key players in the plot to falsify the accounts and hide the bottom-line truth from everyone. It is also clear that all the culprits-from Raju down to the finance guys-did everything possible to give SEBI and other investigative agencies a run-around and delay the verdict. This is what explains, why it took more than five and a half years to close an open-and-shut case. It took nearly 2 years, involvement of multitude of investigation agencies and over 200 experts, to assess the total damage of the scam perpetrated by Raju. Now, the final figure is a shade under Rs. 8000 crore. A special CBI Court in Hyderabad on April 9, 2015 finally, sentenced all the 10 people who involved in the multi-crore accounting scam and was found guilty of cheating, forgery, destruction of evidence and criminal breach of trust. At last, almost the six-year-old case has reached its logical conclusion. This includes the founder and the Chairman of the company B. Ramalinga Raju. The Court pronounced a 7-year jail term for the founder and also imposed on Raju a fine of Rs. 5 crore. Undoubtedly, the Indian government took quick actions to protect the interest of the investors, safeguard the credibility of India, and the nation's image across the world.

The Satyam scam, involving the misuse of CA, has shattered the dreams of different categories of investors, shocked the government and regulators alike, and led to questioning the accounting practices of statutory auditors and CG norms in India. The accounting scandal at Satyam has raised several governance questions about the company's board and its auditors. The most perplexing question is: "Why did not the oversight mechanisms at Satyam uncover the fraud sooner?" One CG expert claims that a lax regulatory system in India bears at least some of the blame. Here, Bhasin [13] commented as: "CG in India was late on the scene, it is more politically motivated than legally based and regulatory laws and agencies are burdened with the complex, slowmoving legislative and judicial processes. The Satyam scam has exposed huge cracks in 
India's CG structure sand system of regulation through the SEBI, Ministry of Corporate Affairs and the SFIO. Unless the entire system is radically overhauled and made publicly accountable, corrupt corporate practices will recur, robbing wealth from the exchequer, public banks and shareholders. Thus, a governance disaster was predictable." Moreover, Satyam fraud has forced the government to re-write CG rules and tightened the norms for auditors and accountants. The Indian affiliate of PwC "routinely failed to follow the most basic audit procedures. The SEC and the PCAOB fined the affiliate, PwC India, \$7.5 million: in what was described as the largest American penalty ever against a foreign accounting firm" [38]. According to Mr. Chopra [39], President of ICAI, "The Satyam scam was not an accounting or auditing failure, but one of CG. This apex body had found the two PwC auditors 'prima-facie' guilty of professional misconduct." The CBI, which investigated the Satyam fraud case, also charged the two auditors with complicity in the commission of the fraud by consciously overlooking the accounting irregularities. As Krishnan [40] pointed out, "Yet both Satyam's internal as well as statutory auditors did not bring it to anyone's notice. Well, the internal auditor hauled up by SEBI has frankly admitted that he did notice differences in the amounts billed to big clients, such as Citigroup and Agilent, when he scoured Satyam's computerized accounts. But when he flagged this with Satyam's finance team, he was fobbed off with the assurance that the accounts would be 'reconciled'. Later, he was 'assured' that the problem had been fixed."

\section{References}

[1] Bhasin, M.L. (2016) Survey of Creative Accounting Practices: An Empirical Study. Wulfenia, 23, 143-162.

[2] Kaul, V. (2015) Satyam Scam: Ramalinga Raju, the Man Who Knew Too Much, Gets 7 Years in Jail. 10 April.

[3] Fernando, A.C. (2010) Satyam: Anything but Satyam. Loyala Institute of Business Administration. www.publishingindia.com

[4] Agrawal, S. and Sharma, R. (2009) Beat This: Satyam Won Awards for Corporate Governance, Internal Audit.

http://www.vccircle.com/news/technology/2009/01/09/beat-satyam-won-awards-corp-gove rnance-internal-audit

[5] Bhasin, M.L. (2013) Corporate Accounting Scandal at Satyam: A Case Study of India's Enron. European Journal of Business and Social Sciences, 1, 25-47.

[6] Bhasin, M.L. (2013) Corporate Accounting Fraud: A Case Study of Satyam Computer Limited. Open Journal of Accounting, 2, 26-38. http://dx.doi.org/10.4236/ojacct.2013.22006

[7] Willison, R. (2006) Understanding the Offender/Environment Dynamic for Computer Crimes. Information Technology \& People, 19, 170-186. http://dx.doi.org/10.1108/09593840610673810

[8] Ramachadran, S. (2009) Raju Brings Down Satyam, Shakes India. Asia Times Online Ltd.

[9] Bhasin, M.L. (2016) Revisiting the Satyam Accounting Scam: A Case Study. International Journal of Management and Social Sciences Research, 5, 31-46.

[10] Wharton (2009) Scandal at Satyam: Truth, Lies and Corporate Governance. http://knowledge.wharton.upenn.edu/ 
[11] Dixit, N. (2009) What Happened at Satyam? 1 March.

[12] Kripalani, M. (2009) India's Madoff Satyam Scandal Rocks Outsourcing Industry. Business Week.

[13] Bhasin, M.L. (2010) Corporate Governance Disclosure Practices: The Portrait of a Developing Country. International Journal of Business and Management, 5, 150-167.

[14] Ingram, K. (2015) India's Satyam Scandal: A Blessing in Disguise? Recorder Printing and Publishing LLC.

[15] Bhasin, M.L. (2015) Forensic Accounting: Perspectives and Prospects. Pakistan Accountant, Oct-Dec 2015, 44-48.

[16] Bhasin, M.L. (2016) Debacle of Satyam Computers Limited: A Case Study of India's Enron. Wulfenia, 23, 124-162.

[17] Bhasin, M.L. (2016) Contribution of Forensic Accounting to Corporate Governance: An Exploratory Study of an Asian Country. International Business Management, 10, 479-492.

[18] Bhasin, M.L. (2015) Creative Accounting Practices in the Indian Corporate Sector: An Empirical Study. International Journal of Management Science and Business Research, 4, 3552.

[19] Bhasin, M.L. (2013) Corporate Governance and Role of the Forensic Accountant: An Exploratory Study of an Asian Country. Amity Business Review, 14, 48-71.

[20] Bhasin, M.L. (2016) Strengthening Corporate Governance through an Audit Committee: An Empirical Study. Wulfenia, 23, 2-27.

[21] Bhasin, M.L. (2008) Corporate Governance and Role of the Forensic Accountant. Chartered Secretary, 38, 1361-1368.

[22] Verma, R. (2009) Satyam Fraud Methodology Revealed. 29 April. www.accountancyage.com

[23] Ramana, K.V. (2009) 7,561 Fake Invoices = Rs. 5,117 Crore "Sales". Daily News Analysis, 15 April. http://www.dnaindia.com

[24] Bhasin, M.L. (2012) Audit Committee Mechanism to Improve Corporate Governance: Evidence from a Developing Country, Modern Economy, 3, 856-872. http://dx.doi.org/10.4236/me.2012.37109

[25] Bhasin, M.L. (2011) Corporate Governance Disclosure Practices: The Portrait of a Developing Country. International Review of Business Research Papers, 7, 393-419.

[26] Bamahros, H.M. and Bhasin, M.L. (2016) Audit Committee Characteristics and Unexpected Accruals: An Empirical Study of Malaysia. Wulfenia, 23, 181-199.

[27] Bhasin, M.L. (2012) Corporate Accounting Frauds: A Case Study of Satyam Computers Limited. International Journal of Contemporary Business Studies, 3, 16-42.

[28] Shirur, S. (2011) Tunneling vs. Agency Effect: A Case Study of Enron and Satyam. Vikalpa, $36,9-20$.

[29] SFIO (2009) SFIO Report. The Pioneer, New Delhi, 4 May 2009, 10.

[30] Bhasin, M.L. (2007) Forensic Accounting: A New Paradigm for Niche Consulting. The Chartered Accountant Journal, 1000-1010.

[31] Bhasin, M.L. (2015) Menace of Frauds in Banking Industry: Experience of a Developing Country. Australian Journal of Business and Management Research, 4, 21-33.

[32] Winkler, D. (2010) India's Satyam Accounting Scandal. The University of Iowa Center for International Finance and Development. http://blogs.law.uiowa.edu

[33] Brown, V.L., Daugherty, B.E. and Persellin, J.S. (2014) Satyam Fraud: A Case Study of In- 
dia's Enron. Issues in Accounting Education, 29, 419-442.

[34] ICAI (2014) The Institute of Chartered Accountants of India Has Imposed a Life-Time Ban on Four Auditors. 22 April 2014.

[35] Shubhashish (2015) All That You Need to Know about the Satyam Scam. DNA, 9 April.

[36] Bhasin, M.L. (2016e) Unethical Creative Accounting Culture at Satyam Computers Limited: A Case Study of India's Enron. International Journal of Business and Social Research, 6, 24-48.

[37] ICAI (2009) ICAI Finds Ex-Satyam CFO, Price Waterhouse Auditors Guilty. www.OutlookIndia.com

[38] Norris, F. (2011) Indian Accounting Firm Is Fined \$7.5 Million over Fraud at Satyam. The New York Times, 5 April 2011.

[39] Chopra, A. (2011) Satyam Fraud, Not an Accounting Failure. Business Standard, 25 January. http://www.business-standard.com

[40] Krishnan, A. (2014) Finally, the Truth about Satyam. The Hindu Business Line, 18 July.

\section{Submit or recommend next manuscript to SCIRP and we will provide best service for you:}

Accepting pre-submission inquiries through Email, Facebook, LinkedIn, Twitter, etc. A wide selection of journals (inclusive of 9 subjects, more than 200 journals)

Providing 24-hour high-quality service

User-friendly online submission system

Fair and swift peer-review system

Efficient typesetting and proofreading procedure

Display of the result of downloads and visits, as well as the number of cited articles Maximum dissemination of your research work

Submit your manuscript at: http://papersubmission.scirp.org/

Or contact ojacct@scirp.org 